\title{
“Owned Them Like a Father": Labor Contractors, Port Workers, and the Makings of Ethnicity in SingAPORE
}

\author{
Laura Yan \\ Columbia University
}

\begin{abstract}
Despite the importance of ports to the Indian Ocean world, labor contracting systems in ports remain understudied. By focusing on ethnic divisions of labor among port workers in colonial Singapore from the 1930s to the 1950s, this article shows how labor contractors constructed these divisions and how social organization in modern Singapore is rooted in labor contracting at the port. Past scholarship has explained merchants' propensity to form partnerships within the same kin or ethnic circles with the notion of trust: that those of the same kin or ethnicity could be trusted more easily. However, this article argues that labor contractors often recruited migrant workers from the contractors' home villages and regions because shared kinship and ethnicity allowed contractors to better control workers' laboring, social, and cultural life. Performances of shared kinship and ethnicity gave contractors power as both employers and community leaders. After World War II, port workers also solidified ethnic divisions by organizing into unions along the lines of ethnicity, and they secured benefits as ethnic blocs, rather than for all port workers. This post-war moment of organizing labor by ethnicity has shaped labor activism in Singapore today as migrant workers continue to strike in ethnic blocs to protest disparities in working conditions between workers of different ethnicities.
\end{abstract}

\section{INTRODUCTION}

On March 6, 1948, a rare event occurred in the port of Singapore. All Indian and Chinese laborers at the Singapore Harbour Board (SHB) stopped work for four hours because of

(C) Laura Yan. This is an Open Access article distributed under the terms of the Creative Commons License CC BY NC SA, which permits users to share, use, and remix the material provided they give proper attribution, the use is noncommercial, and any remixes/transformations of the work are shared under the same license as the original. 
the death of B. Govindasamy, the former head of the Indian Labour Company who had supplied over 3,000 workers to the SHB. ${ }^{1}$ Work stoppages were frequent at the SHB after World War II, but this case is distinctive for two reasons. Firstly, the power of contractors was waning. Govindasamy had been one of the three major labor contractors at the Singapore harbor, along with Tan Chong Chew of the Tanjong Pagar Labour Company and Ching Kee Sun of the Cantonese Labour Syndicate. In October 1947, after multiple workers' strikes and the SHB's growing dissatisfaction with contractors' high margins of profit, the SHB began negotiations with labor unions to end the contractor system and shift towards direct employment of workers by the Harbor Board. Secondly, workers of all ethnicities stopped working. This was an impressive feat because unity was fraught between Chinese and Indian laborers on the waterfront. The death of Govindasamy was clearly important to warrant such a large-scale stoppage by united workers of all ethnicities.

Paradoxically, labor contractors like Govindasamy themselves made sure to foster and maintain ethnic divisions amongst workers. The makings of the ethnic divisions of labor had deep roots in existing kinship networks. In this article, I show that employers deployed kinship and ethnicity as tactics to assume paternalist control over workers' laboring, social, and cultural life, thus retaining workers when formal contracts and benefits did not exist. Contractors often chose to work with their own kin members because this enabled them to wield the dual roles of employer and community leader. ${ }^{2}$ These roles allowed employers to bypass formal contracts and benefits by presenting themselves as providers to workers through displays of generosity, such as granting advances to workers and hosting religious festivals. In an oral history interview, S. L. Perumal (Govindasamy's successor as head of the Indian Labour Company) claimed that advances to workers provided them with a semblance of security during a time when workers did not have a formal contract. For port authority officials, contractors' practices as employers-cum-community leaders translated into beliefs that relationships between contractors, mandores (foremen), and workers were like family because of their shared

\footnotetext{
1 "Malayan security services weekly summary No. 14," 10 Apr. 1948, The National Archives of the UK/Foreign and Commonwealth Office (hereafter: TNA/FCO/) 141/15957. The number of workers who stopped was likely around 8,000. P.A.T. Chrimes, "Singapore harbour board labour force as of June 1947," TNA/FCO/141/14594.

${ }^{2}$ On the dual roles of a merchant household, see: C.A. Bayly, "The family firm," in The Oxford India Anthology of Business History, ed. Medha M. Kudaisya (New Delhi: Oxford University Press, 2011), 171.
} 
village roots and ethnicity. Chen Nee Sian, an SHB officer in the 1950s, said mandores 'owned' the workers 'like a father.' 3

Colonial officials, scholars, and employers themselves have explained that kin members were more likely to be hired because they were more trustworthy. Past scholarship on what may be called family firms or trading diasporas has often assumed that shared kinship, ethnicity, or religion produced inherent trust between merchants, and so merchants worked with others from the same kin or ethnic group. More recently, scholars have argued that trust within kin or ethnic networks was not unconditional; trust was governed by circulation of information within merchant networks so that members could check each other's reputations. ${ }^{4}$ Furthermore, merchants did not always work with those of the same kin or ethnicity. Instead, they sometimes relied on agents or merchants of a different ethnicity because of their access to local trading networks. ${ }^{5}$

This scholarship on trust has largely focused on sprawling mercantile families and on how trust operated between merchants. From the point of view of migrant workers on the Singapore waterfront, what appeared to be trust within a kin or ethnic group disguised contractors' and mandores' tactics to retain workers. The workers were migrants and reliant on contractors to provide access to jobs and housing, which meant that workers were less likely to be able to leave the contractors' employ. This form of power over workers could be misconstrued as employers hiring kin because they were more trustworthy, rather than as being easier to retain because these kin members were migrants and possessed less social capital than local workers. Kinship was also negotiated and predicated on perceptions of familial closeness and distance, which required both employers' and workers' acknowledgement and performance, such as through visits on festival days to pay respect.

After the end of the contractor system, ethnic divisions of labor lived on in the form of ethnically divided unions. The case of the port workers in Singapore shows that race and ethnicity can be essential to modern labor organizing, despite the deep-seated assumption in scholarship that these forms of identity can only hinder labor organizing because they prevent solidarity. Race and ethnicity were not merely pre-capitalist relics,

\footnotetext{
${ }^{3}$ Chen Nee Sian, interview by Patricia Lee, 16 Sep. 2003, interview 002796, reel 4, transcript, Oral History Centre, National Archives of Singapore (hereafter: NASOHC).

${ }^{4}$ Sebouh David Aslanian, From the Indian Ocean to the Mediterranean: The global trade networks of Armenian merchants from New Julfa (Berkeley: University of California Press, 2011), 179-80; Claude Markovits, The Global World of Indian Merchants, 1750-1947: Traders of Sind from Bukhara to Panama (Cambridge: Cambridge University Press, 2000), 261-4.

${ }^{5}$ Francesca Trivellato, The Familiarity of Strangers: The Sephardic diaspora, Livorno, and cross-cultural trade in the early modern period (New Haven: Yale University Press, 2009), 4-9, 155; Markovits, The Global World of Indian Merchants, 256.
} 
colonial categories, or employers' tools to prevent labor solidarity. ${ }^{6}$ In Singapore, port workers maintained ethnic divisions of labor to secure employment and organize into unions. From the port workers' perspective, race and ethnicity, rather than a universalist conception of labor, were foundational to organizing. Labor history in Singapore has pointed to how village, dialect group, and ethnicity defined the working and social life of migrant workers before World War II. ${ }^{7}$ In contrast, scholars have argued, in the late 1940s and 1950s workers expressed demands in terms of global anti-colonialism and were increasingly organized by trade unions rather than clan or dialect associations. ${ }^{8}$ This article shows that not only did kin and ethnic ties endure for longer than previously understood, but also that these ties made labor organizing possible.

Contractors' divisions of labor reified colonial ideas about ethnicized capacities of labor and laid the foundation for the categorization of Singaporean society into the three main races of Chinese, Malay, Indian or Other (CMIO). This idea of the three main races was one of the pillars of post-colonial governance in Singapore under the People's Action Party (PAP). ${ }^{9}$ To understand this system of social organization, we must study how ethnic divisions emerged from the recruitment of migrant labor. The discussion of race and

\footnotetext{
${ }^{6}$ Dipesh Chakrabarty, Rethinking Working-Class History: Bengal, 1890-1940 (Princeton, NJ: Princeton University Press, 1989); Rajnarayan Chandavarkar, The Origins of Industrial Capitalism in India: Business strategies and the working classes in Bombay, 1900-1940 (Cambridge: Cambridge University Press, 1994); Tirthankar Roy, "Sardars, jobbers, kanganies: The labour contractor and Indian economic history," Modern Asian Studies, 42, 5 (2008), 971-998. For further discussion of intermediaries and mobile labor, see Ravi Ahuja, "Networks of subordination - networks of the subordinated: The ordered spaces of South Asian maritime labour in an age of imperialism (c. 1890-1947)," in The Limits of British Colonial Control in South Asia: Spaces of disorder in the Indian Ocean region, eds. Ashwini Tambe and Harald FischerTiné (London: Routledge, 2008), 13-48; G. Balachandran, "Making coolies, (un)making workers: 'Globalizing' labour in the late-19 $19^{\text {th }}$ and early-20 ${ }^{\text {th }}$ centuries," Journal of Historical Sociology, 24, 3 (2011), 266-296.

${ }^{7}$ James Warren, Rickshaw Coolie: A people's history of Singapore, 1870-1940 (Singapore: Oxford University Press, 1986); Jason Lim, A Slow Ride into the Past: The Chinese trishaw industry in Singapore, 1942-1983 (Clayton, Victoria: Monash University Publishing, 2013); Stephen Dobbs, The Singapore River: A social history, 1819-2002 (Singapore: National University of Singapore Press, 2003).

${ }^{8}$ Liew Kai Khiun, "The anchor and the voice of 10,000 waterfront workers: Jamit Singh in the Singapore story (1954-63)," Journal of Southeast Asian Studies, 35, 3 (2004): 459-478; Liew Kai Khiun, "Labour formation, identity, and resistance in HM dockyard, Singapore (1921-1971)," International Review of Social History, 51, 3 (2006): 415-439; Gareth Curless, “"The people need civil liberties': Trade unions and contested decolonisation in Singapore," Labor History, 57, 1 (2016): 53-70; Gareth Curless, "The triumph of the state: Singapore's dockworkers and the limits of global history, c. 1920-1965," The Historical Journal 60, 4 (2017): 1097-1123; Dobbs, The Singapore River, 77.

${ }^{9}$ Since Singapore's independence in 1965, the PAP government has continued to deploy colonial categories of race that have flattened and essentialized the complexities of regional and linguistic differences within ethnic groups. The power of these racial categories has only increased as the PAP has deployed ideas of multiracial harmony and multiculturalism to justify its policies. Chua Beng Huat, Communitarian Ideology and Democracy in Singapore (London; New York: Routledge, 1995); Nirmala Purushotam, Disciplining Differences: Race in Singapore (Singapore: National University of Singapore, 1995); John Clammer, Race and State in Independent Singapore, 1965-1990: The cultural politics of pluralism in a multiethnic society (Brookfield, VT: Ashgate, 1998); Lily Kong and Brenda S.A. Yeoh, The Politics of Landscapes in Singapore: Constructions of "nation" (Syracuse, NY: Syracuse University Press, 2003), 35; Daniel P.S. Goh et al., eds., Race and Multiculturalism in Malaysia and Singapore (London; New York: Routledge, 2009); Kwen Fee Lian, ed., Multiculturalism, Migration, and the Politics of Identity in Singapore (Singapore: Springer, 2016).
} 
ethnicity in Singapore is curiously disconnected from Singapore's labor history. Chua Beng Huat and Eddie Kuo have argued that the colonial economy based on entrepot trade 'imposed an ethnically determined division of labour' with Europeans at the top of the hierarchy and Chinese laborers at the bottom. ${ }^{10}$ But they and other scholars of race in Singapore have not fully elaborated the logics behind colonial categories of race and how actors created, maintained, or negotiated ethnic divisions of labor. While scholars have made clear that colonial and post-colonial governments in Singapore attempted to organize society by race, I show how the racial organization of society partly stems from labor recruitment practices in the port that fostered ethnic divisions of labor.

The CMIO system in Singapore is a legacy of the nineteenth-century mobilization of labor around the Indian Ocean to work on new steam ships and ports serving imperial trade and shipping. Despite the importance of port cities in the Indian Ocean, few studies have focused on port workers. Indian Ocean studies so far have emphasized the cosmopolitanism of merchants and intellectuals who lived in and traveled through multicultural cities; their encounters with each other informed their sense of similarity and difference between ethnic groups. ${ }^{11}$ However, the system of labor contracting in port cities, and how it contributed to divisions of labor by race, remains understudied. ${ }^{12}$

I use both the terms 'race' and 'ethnicity' because ethnicity - differentiation between social groups based on ideas of common origin, language, religion, or other social institutions - has been transformed and flattened into race in Singapore. For example, the different dialect groups of Hokkien, Teochew, Cantonese, Hakka, and Hainanese now fall into the category of race as 'Chinese.' The two concepts are inseparable in Singapore today. ${ }^{13}$ With the awareness of the historical and historiographical slippages between the

\footnotetext{
${ }^{10}$ Chua Beng Huat with Eddie C.Y. Kuo, "The making of a new nation: Cultural construction and national identity," in Communitarian Ideology and Democracy in Singapore, ed. Chua Beng Huat, (London; New York: Routledge, 1995), 1012.

${ }^{11}$ For discussions of cosmopolitanism and Indian Ocean studies, see: Edward Simpson and Kai Kresse, "Cosmopolitanism contested: anthropology and history in the western Indian Ocean," in Struggling with History: Islam and cosmopolitanism in the western Indian Ocean, ed. Edward Simpson and Kai Kresse (New York: Columbia University Press, 2008), 1-41; Nile Green, "The waves of heterotopia: Toward a vernacular intellectual history of the Indian Ocean," American Historical Review, 123, 3 (2018), 846-74.

${ }^{12}$ Scholarship on maritime labor has been more attentive to the makings of race and ethnicity, especially regarding hierarchies of labor. See: Janet Ewald, "Crossers of the sea: Slaves, freedmen, and other migrants in the northwestern Indian Ocean, c. 1750-1914," American Historical Review, 105, 1 (2000): 69-91; Ravi Ahuja, "Mobility and containment: The voyages of South Asian seamen, c. 1900-1960," International Review of Social History, 51, S14 (2006): 111-41; G. Balachandran, "Making coolies," 266-96.

${ }^{13}$ Kwen Fee Lian has used the term 'ethnoracialization' to describe how the PAP saw the relationships between society, culture, race, ethnicity, and the individual as interchangeable. Kwen Fee Lian, "Multiculturalism in Singapore: Concept and practice," in Multiculturalism, Migration, and the Politics of Identity in Singapore, ed. Kwen Fee Lian (Singapore: Springer, 2016), 15.
} 
two terms, I use the term 'race' when I describe the CMIO categories of difference and when historical actors used this term, and I choose to use 'ethnicity' to describe differentiation based on culture or language, such as Tamil, Hokkien, and Cantonese.

\section{The Formation of the Port}

In 1819, the English East India Company (EIC) established modern Singapore as a stop on the trade route between India and China. The EIC and country traders sold Indiangrown opium in China to purchase tea for sale, and the profits from this trade fueled the British imperial economy. Located at the hinge between the Indian Ocean and the South China Sea, Singapore briefly played the role of an entrepot between India and China, and quickly attracted traders from around the region. ${ }^{14}$ The opening of the Suez Canal in 1869 and increased demand for raw materials such as tin (and eventually rubber) from the Malay Peninsula and the Dutch East Indies transformed Singapore into a staple port. ${ }^{15}$ Intensified trade and increasing numbers of steam ships required the mobilization of laborers to work on lighter boats, ships, and on wharves to load and unload cargo for import and export. Faced with labor supply issues, trading and shipping companies recruited workers from southern China, southern India, and the Malay hinterland. In 1819, Singapore's population was about 1,000 . By 1938 , the population was over 700,000 and it was composed of approximately $77 \%$ Chinese, $10 \%$ Malays, and 9\% Indians. ${ }^{16}$

Before the opening of the Suez Canal, the port of Singapore was centered around the Singapore River, which flowed to the Singapore Strait, a waterway south of Singapore Island. Ships anchored at the mouth of the river where workers transported goods off the ship and moved them by boat up the Singapore River towards godowns (warehouses) located on the riverbanks. ${ }^{17}$ By the 1860 s, the river was crowded with boats and was plagued with problems of silting; the river could not accommodate new steam ships that had larger draughts and thus required deeper water. The need for docking facilities to accommodate steam ships prompted port development at a deep-water harbor west of the Singapore River. Established in 1864, the Tanjong Pagar Dock Company built docks and wharves at the harbor and, by the end of the nineteenth century, the company had

\footnotetext{
${ }^{14}$ Carl Trocki, Singapore: Wealth, power and the culture of control (London: Routledge, 2006), 7.

${ }^{15}$ Ibid., 12; William Huff, The Economic Growth of Singapore: Trade and development in the twentieth century (Cambridge: Cambridge University Press, 1994), 8.

${ }^{16}$ Government of the Straits Settlements, Straits Settlements Blue Book for the Year 1938 (Singapore: 1940), 716-17.

${ }^{17}$ Dobbs, The Singapore River, 64.
} 
monopolized port facilities at the harbor. ${ }^{18}$ In 1905, after it became clear that the dock company lacked capital to expand the port, the Government of the Straits Settlements (which included Singapore, Penang, and Malacca) appropriated the company. ${ }^{19}$ In 1913 , the Straits Government and Legislative Council established the Singapore Harbour Board. To prevent monopolies, the SHB did not have exclusive rights at the port to move cargo but it did have exclusive rights to supply labor for the movement of cargo. ${ }^{20}$

In the nineteenth century, most European employers needed to go through Chinese brokers to recruit workers, which increased the costs of labor. ${ }^{21}$ But the Tanjong Pagar Dock Company was supposedly 'far-seeing' and employed their own recruiter to transport migrants at the company's cost, from Amoy and Swatow in southeastern China. ${ }^{22}$ Labor contracting thus helped ensure labor supply for the company by bypassing brokers in China and in Singapore. Following the practice of the Tanjong Pagar Dock Company, the SHB employed most of its labor through contractors. Contractors turned to mandores (gang foremen) to recruit a specific number of laborers based on information from shipping companies or from the SHB about the amount and type of cargo to be loaded or unloaded. Shipping fluctuated daily so the SHB retained extra workers to meet any spikes in shipping. Labor contractors could handle the day-to-day issues of recruitment, pay, housing, and discipline - as well as speak the workers' language, unlike the Englishspeaking SHB officers. The SHB paid labor contractors by ton and the contractors then paid the workers at daily rates. ${ }^{23}$ By employing most of the workers through contractors, the SHB did not pay for wages or maintenance costs when there was no work. It was essential to colonial authorities, shipping companies, and local boat owners to limit costs of labor when there was less work. Low wages reduced the cost of running the ports, attracted more shipping, and enabled the SHB to compete with other ports in the region. Thus, the SHB and labor contractors established a system of casual labor similar to those in other ports around the world during the nineteenth and early twentieth centuries. ${ }^{24}$

\footnotetext{
${ }^{18}$ John Rumney Nicholson, "The Tanjong Pagar Dock Company," in One Hundred Years of Singapore, Volume II, eds. Walter Makepeace, Gilbert E. Brooke, and Roland St. J. Braddell (Singapore: Oxford University Press, 1991 [1921]), 11.

${ }^{19}$ George Bogaars, The Tanjong Pagar Dock Company 1864-1905 (Singapore: A.G. Banfield, 1956), 228-9.

${ }^{20}$ Ellen Wong, "The Singapore Harbour Board, 1913-1941" (B.A. thesis, University of Malaya, 1960), 5-7.

${ }^{21}$ Geoffrey Drage et al., Royal Commission on Labour Foreign Reports Vol. II: The colonies and the Indian Empire (London: Eyre and Spottiswoode, 1892-1894), 97.

${ }^{22}$ C. Wilson, "Annual report of the labour department, Malaya," 1938, British Library/India Office Records (hereafter: BL/IOR/) L/PJ/8/262; Report of the Commissioners Appointed to Enquire into the State of Labour in the Straits Settlements and the Protected Native States (Singapore: Government Printing Office, 1891), 12.

${ }^{23}$ Wong, "The Singapore Harbour Board," 32.

${ }^{24}$ Sam Davies, Colin J. Davis, David de Vries, Lex Heerma van Voss, Lidewij Hesselink, and Klaus Weinhauer, ed., Dock Workers: International explorations in comparative labour history, 1790-1970 (Aldershot: Ashgate, 2000).
} 


\section{"Very Racial": The Labor Contractor System and Colonial TYPOLOGIES OF LABOR}

Ronald Milne, a traffic manager at the SHB, described the gangs of workers in the late 1940s as 'very racial.' He said that Indian contractors supplied Indian gangs, Cantonese contractors supplied Cantonese gangs, and Hokkien contractors supplied Hokkien gangs. ${ }^{25}$ Although Milne's statement obscured contractors' practice of hiring some mandores of a different ethnicity, it is largely accurate. The three major labor contractors for the SHB were the Tanjong Pagar Labour Company (TPLC), the Cantonese Labour Syndicate (CLS), and the Indian Labour Company (ILC). Hokkien businessman Tan Chong Chew managed the TPLC, where the majority of workers were Hokkien. ${ }^{26}$ Ching Kee Sun and five other Cantonese partners owned the CLS, which employed Cantonese workers. ${ }^{27}$ B. Govindasamy and K. P. Mohamed Yusuff were partners at the ILC, which employed mostly Indian workers along with a few hundred Chinese workers working under Chinese mandores. ${ }^{28}$

Milne's use of the term 'racial' shows a slippage between race and ethnicity that characterized discussions of labor. Broad categories of 'race,' meaning Chinese, Malay, and Indian, began to appear in Straits Settlements colonial records in the late nineteenth century. The categories of race were founded upon ideas about ethnicized capacities of labor, which were delineated by dialect group and region. British colonial archives are replete with the typologies of the 'Cantonese artisan and mechanic' or 'Cantonese

\footnotetext{
${ }^{25}$ Ronald Milne, interview by Daniel Chew, 17 Oct. 1984, interview 000447, reel 31, transcript, NASOHC.

26 "Late Mr. Tan Kheam Hock," Malaya Tribune (2 May 1922):

http://eresources.nlb.gov.sg/newspapers/Digitised/Article/maltribune19220502-1.2.15 [Accessed: 5 Sep. 2019]; "Wharf Workers Meet," Straits Times (5 June 1939):

http://eresources.nlb.gov.sg/newspapers/Digitised/Article/straitstimes19390605-1.2.80 [Accessed: 5 Sep. 2019]. Newspaper articles also refer to separate Cantonese Labour Syndicate "coolie lines" (workers' quarters) and Hokkien lines run by the Tanjong Pagar Labour Company. "Singapore raid," Straits Times (2 Feb. 1935):

http://eresources.nlb.gov.sg/newspapers/Digitised/Article/straitstimes19350202-1.2.71 [Accessed: 10 Sep. 2020]; "Man hurtles to his death," Malaya Tribune (28 Sep. 1938):

http://eresources.nlb.gov.sg/newspapers/Digitised/Article/maltribune19380928-1.2.66 [Accessed: 10 Sep. 2020]; "Monthly review of Chinese Affairs, September 1938," 5 Oct. 1938, The National Archives/Colonial Office (hereafter: TNA/CO/) 273/641/6. The Tanjong Pagar Labour Company also employed about 400 Indian workers in the early 1930s. C.D. Ahearne, "Straits settlements annual report of the Labour Department," 1931, BL/IOR/L/PJ/8/258; "Straits settlements annual report of the working of the Labour Department," 1933, BL/IOR/L/PJ/8/258.

27 “The Cantonese Labour Syndicate," 20 Dec. 1947, National Archives of Singapore/Registry of Business/ [hereafter: NAS/ROB/] 022/12047; Ahearne, "Straits settlements annual report," 1931, BL, IOR/L/PJ/8/258; "Straits settlements annual report," 1933, BL/IOR/L/PJ/8/258.

${ }^{28}$ Ahearne, "Straits settlements annual report," 1931, BL/IOR/L/PJ/8/258; "Straits settlements annual report," 1933, BL/IOR/L/PJ/8/258; "Came to Malaya in a sailing vessel," Straits Times (25 May 1933):

http://eresources.nlb.gov.sg/newspapers/Digitised/Article/straitstimes19330525-1.2.130 [Accessed: 10 Sep. 2020]; Sundarajulu Lakshmana Perumal, interview by Lim How Seng, 28 Apr. 1982, interview 000173, reel 1, transcript, NASOHC.
} 
stevedores' (jobs that were thought of as skilled work) in contrast with the 'Hokkien and Teochiu [Teochew] unskilled labourer,' who was often categorized as a porter, longshoreman, or dock worker. ${ }^{29}$ Indian workers were also considered unskilled. ${ }^{30}$ These conceptions of various ethnicities' different capacities for labor and skill continued beyond the colonial period. Early scholarship on the SHB inherited these categories, as demonstrated by a study of SHB workers that differentiated between skilled Chinese artisans and unskilled Indian laborers. ${ }^{31}$

Excluded from these discussions of racial and ethnicized categories of labor is the role of labor contractors in shaping these categories. Contractors' divisions of labor helped create and solidify categories of ethnicity and associated ideas about capacity for labor. The three contracting companies at the Singapore harbor supplied laborers for different functions in the port. The Tanjong Pagar Labour Company primarily supplied wharf laborers, the Cantonese Labour Syndicate worked mainly as stevedores for the Mansfield shipping line, and the Indian Labour Company was responsible for stevedores for ships and wharf laborers for jetty work. ${ }^{32}$ Wharf work was considered less skilled than stevedoring work because wharf work did not require knowledge of how to distribute cargo in the hold to ensure balance. Hokkiens and Indians were categorized as unskilled longshoremen and dock workers partly because the TPLC and ILC employed the highest number of workers in the wharves and godowns. Cantonese workers were known as stevedores due to CLS dominance in stevedoring. Furthermore, Cantonese workers made up the majority in artisan and mechanical workshops at the dockyard, and this was considered skilled work. ${ }^{33}$ Charles Foo, an engineering apprentice at the Singapore Harbour Board dockyard in 1959 recalled that Cantonese workers formed the majority in the dockyard: 'If you are outside fitting on a ship and if you can't speak Cantonese, then

\footnotetext{
${ }^{29}$ W. Evans, "Annual report of the Chinese protectorate straits settlements," 1897-1898, School of Oriental and African Studies/Wilfred Blythe Collection [hereafter: SOAS/WBC/] PP MS 31/Box 1/File 1; "Dispatches to the Secretary of State," 3 Feb. 1930, SOAS/WBC/PP MS 31/Box 3/File 15; Mak Lau-Fong and Him M. Lai, "Occupational structures of Chinese immigrants in early Malaya and North America," Southeast Asian Journal of Social Science, 20, 1 (1992), 50.

${ }^{30}$ Colonial officials described Chinese workers as industrious but prone to strikes, Malays as unsuited to industry and thus unimportant, and Indian workers (mostly Tamil) as hardworking but not as industrious as Chinese workers and requiring British protection. J.M. Barron, "Annual report of the Labour Department, Malaya," 1935, BL/IOR/L/PJ/8/259. See also: Syed Hussein Alatas, The Myth of the Lazy Native: A study of the image of the Malays, Filipinos and Javanese from the $16^{\text {th }}$ to the $20^{\text {th }}$ century and its function in the ideology of colonial capitalism (London: F. Cass, 1977).

${ }^{31}$ Wong, "The Singapore Harbour Board," 30.

${ }^{32}$ Perumal, reel 1, NASOHC.

${ }^{33}$ Mak and Him, "Occupational structures," 49-50. Cantonese dominance in workshops is also indicated by the concentration of Cantonese workers in the mechanical shops and in residences at King's Dock or at the Singapore Harbour Board quarters on Morse Road. Singapore Association of the Wong Clan of Toishan Member Subscription Book, 1947, National Archives of Singapore [hereafter: NAS/] NA 257/836/1102/267.
} 
you are in trouble.' ${ }^{34}$ Divided by ethnicity and dialect, different contractors each monopolized a port work function, thus creating ethnic blocs of workers and shaping colonial ideas about racialized or ethnicized capacity of work.

\section{The Logic and Practices of Kinship and Ethnicity}

The contractors hired most of their workers from outside Singapore, partly because of labor scarcity in the city. Govindasamy's kin network was small and insufficient for supplying over 3,000 workers to the SHB. Although they hired some workers in Singapore, the majority were recruited through intermediaries in India. Contractors were able to recruit through agents in their home villages where they maintained contacts or family. These recruiters then arranged for paid transportation of recruits to Singapore, where the recruits were either housed in SHB quarters that were used by the Indian Labour Company or in rented dwellings of their own in Tanjong Pagar, the neighborhood near the port. Perumal claimed that most of the new recruits were farmers and 'odd-job men' from south India who arrived in Singapore with few skills. Those considered unskilled pulled hand carts on the wharf for around a year before they could transition to stevedoring on ships. ${ }^{35}$ Recruitment of migrants was also the standard because new migrants had less economic and social power. They possessed less access to other jobs, and their options were limited to working for known figures, such as labor contractors. Furthermore, their ability to return to their home country was contingent upon continued employment, because a return ticket was usually provided by the contractor after at least a few years of service.

At the outset, the Indian Labour Company seemed to function like a family firm. Recruitment often followed a custom in the family or village to work abroad. S. L. Perumal, who worked at the ILC with his uncle and father-in-law B. Govindasamy, said that he and Govindasamy came from a family in which it was a 'tradition' for men to travel to Penang, Singapore, and Saigon for business. ${ }^{36}$ The family was spread out among three villages where almost all the residents were related. Perumal claimed that many of their fellow villagers had come to Singapore and worked for him and his uncle. ${ }^{37}$ The logic behind employment of kin has been explained by kin being easier to trust. But scholars have shown that members of transnational trading families did not inherently trust kin and sometimes created other mechanisms of accountability for employed non-

\footnotetext{
${ }^{34}$ Charles Foo, interview by Patricia Lee, 12 June 2008, interview 003327, reel 1, transcript, reel 1, NASOHC.

${ }^{35}$ Perumal, reel 1 , NASOHC.

${ }^{36}$ Ibid.

${ }^{37}$ Perumal, reel 9, NASOHC.
} 
kin. ${ }^{38}$ A similar logic applied to the port. The labor contracting and lighter boat companies that provided the bulk of labor for the Singapore port often hired kin, but not exclusively: they formed partnerships with both kin and non-kin members. ${ }^{39}$ Access to capital and to local networks were factors in decisions to work with kin or non-kin members.

The workers' reliance on their employers for job security and housing could be misunderstood as strong bonds of trust between employer and worker that tethered workers to their jobs. In 1947, colonial officials in Singapore found that most laborers entering Singapore were related to their sponsors by kin or by village ties. When a colonial official asked Chinese shopkeepers why they would not hire locally, they usually responded, 'I could but he would be unreliable, he would ask too much and give too little. I must have a relative, a man from my own village from China whom I can trust. ${ }^{40}$ Although there could have been a sense of affinity with laborers from the same village or kin group that would create trust, it is also clear from this statement that migrant recruits had less power to negotiate wages or working conditions than locals because of migrants' lack of choices for other jobs. When applied to labor, the notion of trust as a factor in merchants' choices to work with kin or co-ethnic fellows must encapsulate the employers' preference for migrants to ensure that workers remained in their employ.

Labor contractors produced an ethnic division of labor that encompassed not only working life but also the worker's social and cultural life. By hiring workers of the same ethnicity, contractors and mandores could showcase religious and cultural practices that enhanced their power as community leaders and thus as employers. The labor contractors hosted religious festivals and theater performances for the workers at the SHB premises. The contractors and mandores also took charge of maintaining cultural practices, such as deductions from wages to pay for joss sticks and festival celebrations. ${ }^{41}$ Hosting festivals and donating to temples bolstered credentials for both roles of employer and community leader because these practices showed that the contractor could fulfill their responsibilities as community leaders to care for their kin and co-ethnic fellows. Perumal portrayed his uncle B. Govindasamy as respected, well-liked, generous, and close to the workers. ${ }^{42}$ Govindasamy conceived of generosity and donations as exchange for labor. Perumal

\footnotetext{
38 Trivellato, The Familiarity of Strangers, 4-9, 155; Aslanian, From the Indian Ocean to the Mediterranean, 179-80; Markovits, The Global World of Indian Merchants, 261-4.

${ }^{39}$ Perumal, reel 1, NASOHC; "Came to Malaya in a sailing vessel,"; Lim, reel 2, NASOHC; Yeo Kok Kheng, interview by Jesley Chua Chee Huan, 10 Nov. 1986, interview 000718, reel 8, transcript, NASOHC.

${ }^{39}$ B.S. Davis, "Note on immigration," 17 Apr. 1947, TNA/FCO 141/14594.

40 "Monthly review of Chinese Affairs, September 1938," 5 Oct. 1938, TNA/CO/273/641/6.

${ }^{41}$ Perumal, reel 2, NASOHC.
} 
claimed that business turnover was high but profits were not, and Govindasamy made many donations to charity and gave money to workers: 'Everybody said that... anybody who goes to Govindasamy Chettiar will not go empty handed...He [Govindasamy] used to say that, "Oh, I am getting the men to work, the sweat is our money, money from their sweat." 43 Although Govindasamy and Perumal admitted that the relationship between contractor and worker was extractive because they earned money from workers' labor, they also framed the relationship as one in which workers' labor transformed into religious giving and help for the workers, rather than into mere profit alone. In doing so, Govindasamy presented himself as a Tamil community leader who maintained care for workers through individualized negotiations for donations, advances, and other ways to meet the workers' material needs.

Individualized negotiations with workers for advances and donations precluded a formal benefits system because contractors considered their ad hoc care to be sufficient. In response to a question about welfare, fringe benefits, and medical care, Perumal responded, 'My uncle was well-known for his treatment of his men. So [if] anybody comes for my uncle's help, they usually get it. ${ }^{44}$ Dealing with workers individually to solve their problems by alleviating tension in a work gang or giving advances also meant that Govindasamy did not need to deal with workers as a solid bloc. Thus, Govindasamy staved off a standardized contract and negotiations with unions, which emerged near the end of his tenure as a labor contractor.

Contractors also consistently hired mandores and gangs of workers who were not of the same ethnicity as the contractor or as the majority of workers at the contracting company. Divisions of workers by ethnicity within the same labor contracting companies allowed contractors to delegate work flexibly and reinforce their status as community leaders through differentiated modes of giving to different ethnicities. The Tanjong Pagar Labour Company employed hundreds of Indian workers, but only the Chinese workers received free quarters, cooked rice, water, and electricity. ${ }^{45}$ At the Indian Labour Company, the workers under Chinese mandores received their pay from the mandore, unlike the directly employed Indian workers who were paid daily rates individually once a month. ${ }^{46}$ Perumal also recalled that the ILC provided free rice and curry for the Indian workers, while the company gave the Chinese mandores money to buy food for their

\footnotetext{
42 Perumal, reel 3, NASOHC.

${ }^{43}$ Perumal, reel 1 , NASOHC.

44 "Monthly review of Chinese Affairs, September 1938," 5 Oct. 1938, TNA/CO/273/641/6.

${ }^{45}$ Perumal, reel 1, NASOHC.
} 
workers outside of the company kitchen. ${ }^{47}$ Perumal claimed that relations between Indian and Chinese workers were good and that the company treated them the same. But it is clear that the Indian Labour Company conceived of Chinese workers as different from Indian workers because Chinese workers could only work under Chinese mandores, who would handle recruitment, pay, and food. This system allowed for the contractors to claim authority as providers of welfare to workers who were of the same ethnicity as him in contrast with workers who were not.

What seemed like practices of ethnicity could also mask exploitation and some workers fought to end these practices. The Tanjong Pagar Labour Company workers went on strike to end deductions from wages for festivals or joss sticks, which cost each worker 30-50 cents (about a day's worth of wages). The workers also compelled the company to begin giving them advances on wages so that they were not forced to borrow money from mandores, who charged interest at around $10 \%$ per month. ${ }^{48}$ After a strike by Indian Labour Company workers in February 1937, an article appeared in a weekly newspaper The Orient Gong that was critical of the ILC's working conditions. According to a physician who treated most of the ILC workers, the workers were suffering from excessive heat and indigestion because of the daily meals of salt fish and brinjals. Workers could not change their diets because they relied on meals provided by the company. ${ }^{49}$ This issue of food caused much discontent among the workers. B. Govindasamy admitted that 'speaking generally, there was considerable unrest among all Tamil coolies.' ${ }^{50} \mathrm{He}$ subsequently sued The Orient Gong for libel and he won the case. ${ }^{51}$ The libel case demonstrates that contractors' claims of welfare, such as providing meals or hosting festivals, could actually be harmful for workers by limiting their choices and reducing their wages. Furthermore, the system of personalized negotiation and providing welfare for workers occasionally broke down and workers used strategies such as strikes and civil action.

Although the role of village headman or community leader provided port employers with power over workers, the same roles also created pressure for employers to provide job opportunities for their kin. Lim Kim Tian was the wealthiest lighter boat owner at the

\footnotetext{
${ }^{46}$ Perumal, reel 2, NASOHC.

47 "Monthly review of Chinese Affairs, September 1938," 5 Oct. 1938, TNA/CO/273/641/6.

48 "Indian editor fined \$200," Straits Times (29 Sep. 1937):

http://eresources.nlb.gov.sg/newspapers/Digitised/Article/straitstimes19370929-1.2.78 [Accessed: 8 Aug. 2020].

49 "Gross, malicious libel," Malaya Tribune (27 Aug. 1937):

http://eresources.nlb.gov.sg/newspapers/Digitised/Article/maltribune19370827-1.2.30 [Accessed: 8 Aug. 2020].

50 "Indian editor fined \$200."
} 
Singapore River. Lim Chwee Pin, his relative and employee, recalled that Lim Kim Tian was considered the headman of their home village in China and Lim Kim Tian maintained this status and reputation through sponsorship of immigration and funding a school in the village. Kinship among boat owners and workers was defined by familial closeness or distance. Lim Chwee Pin said that relations between lighter boat owners and workers were good because they were from the same village and kin group, and thus were able to form intimate connections. But workers were also aware that owners were set apart, despite their shared village connections. Workers acknowledged this hierarchy by visiting lighter boat owners on festival days. These visits were a sign of respect and filial piety. They signaled that the workers and lighter boat owners were of the same kin but the workers, as the visitors, acknowledged that the owners were the elders and took precedence in both familial and workplace hierarchies. ${ }^{52}$

Shipowners with the surname Lim often employed workers with the same surname, but that did not mean that all Lims were able to access jobs. Shipowners provided access to jobs and credit to kin who were considered closer, which was determined by sharing the same ancestor. ${ }^{53}$ For example, Lim Chwee Pin was able to move to Singapore with his mother and work for Lim Kim Tian, despite having never met him, because of perceived familial closeness. Lim Kim Tian was considered Lim Chwee Pin's great-uncle, although Lim Kim Tian was not actually the brother of Lim Chwee Pin's grandfather. Despite this, both parties performed close kinship. Lim Chwee Pin claimed that his family was the second closest family to Lim Kim Tian in Singapore, and Lim Kim Tian and his wife arranged for their transportation to Singapore and provided employment. ${ }^{54}$ These were opportunities that other kin may not have been able to access because Lim Chwee Pin and Lim Kim Tian acknowledged and practiced familial closeness.

\section{WATERFRONT UNIONS}

After the Japanese occupation and the return of British colonial governance, labor unions at the port proliferated. The port was in shambles: the Singapore River was silted up, the harbor was full of shipwrecks, and transit sheds and warehouse space had been destroyed. ${ }^{55}$ Local men were weakened after the severe hardships of occupation and

\footnotetext{
${ }^{51}$ Lim Chwee Pin, interview by Tan Beng Luan, 17 Nov. 1986, interview 000723, transcript, reel 1, NASOHC.

${ }^{52} \mathrm{Lim}$, reel 2, NASOHC.

${ }^{53} \mathrm{Lim}$, reel 3, NASOHC.

55 "Summary of report of enquiry into working of the ports of Singapore, Penang and Fort Swettenham," 24 Oct. 1946, TNA/FCO/141/16870; "Dredging and wreck clearing of Singapore Harbour," 30 Dec. 1946, US National Archives and
} 
insufficient rations, which led to increased pilferage in the port. ${ }^{56}$ Unionization flourished in many sectors of work in Singapore and the General Labour Union (GLU) emerged as a leftist federation of unions. ${ }^{57}$ Workers joined three new unions at the SHB: the SHB Employees Union (SHBEU), the Ship and Wharf Labour Union (SWLU), and the Singapore Harbour Labour Union (SHLU). Unions were organized by ethnicity into Hokkien-, Cantonese-, and Tamil-majority labor unions. ${ }^{58}$ Due to the ethnicized contractor system, the ethnicization of unions also intersected with divisions by contractor. Cantonese Labour Syndicate workers were members of the SWLU and Indian Labour Company workers joined the SHLU. ${ }^{59}$ During the period of nascent unionization after World War II, port workers did not often strike in solidarity with their fellow workers and frequently undermined workers of a different ethnicity by reducing their access to work and replacing them if they were striking.

Scholarship on labor contractors and intermediaries has focused on their power over workers and their role in creating divisions of labor that prevented the formation of a working-class consciousness. ${ }^{60}$ But how workers made and framed their demands within systems of ethnicized labor is less understood. Gareth Curless and Liew Kai Khiun have deepened our understanding of waterfront unions' engagement with ideas of global anticolonialism that lost salience on the waterfront once the PAP co-opted management of labor and took power away from unions. ${ }^{61}$ However, divisions of labor by ethnicity persisted during this moment of cosmopolitan labor organizing described by Curless and Liew. Although labor contracts were abolished at the end of 1947, the structure of labor contracting continued to shape the organization of labor. Rather than treating ethnicity as a pre-capitalist barrier to working class solidarity, I show that it laid the foundation for

Records Administration S/No 136 File Series 279 [Accessed at NAS/NA 2878]; "Harbour Board repairs being rushed," Straits Times (9 Dec. 1945): http://eresources.nlb.gov.sg/newspapers/Digitised/Article/straitstimes19451209-1.2.22 [Accessed: 2 Aug. 2019].

56 "Draft comments on report of London committee on port facilities in South East Asia area," 18 Feb. 1944, The National Archives UK/War Office/203/4300.

${ }^{56}$ On unionization in Singapore, see: S.S. Awbery and F.W. Dalley, Labour and Trade Union Organisation in the Federation of Malaya and Singapore (Kuala Lumpur: H.T. Ross, 1948); Charles Gamba, The Origins of Trade Unionism in Malaya: A study in colonial labour unrest (Singapore: Eastern Universities Press, 1962); Curless, “"The people need civil liberties'."

${ }^{57}$ The Singapore Ship and Wharf Labour Union and the SHB Employees Union were described as Cantonese and Hokkien, respectively. "Chinese unions oppose strike: 1,695 men work," Straits Times (19 Apr. 1948):

http://eresources.nlb.gov.sg/newspapers/Digitised/Article/straitstimes19480419-1.2.13 [Accessed: 10 Sep. 2020]. Security reports of SHLU meetings often described most of the attendees as Indian. "MSS Singapore weekly summary No. 19," 15 May 1948, TNA/FCO/141/15957; "MSS Singapore weekly summary No. 18," 8 May 1948, TNA/FCO/141/15957; "MSS Singapore weekly summary No. 17," 1 May 1948, TNA/FCO/141/15957.

58 "MSS Singapore weekly summary No. 7," 14 Feb. 1949, TNA/FCO/141/15957.

${ }^{59}$ Chandavarkar, The Origins of Industrial Capitalism, 13-14.

${ }^{60}$ Curless, "The triumph of the state;" Liew, "The anchor and the voice." 
large-scale labor organizing at the Singapore port that was successful in securing better pay and working conditions, and eventually decasualization in 1947.

Division of labor by ethnicity was a tool for both contractors and the SHB to recruit, retain, and easily replace laborers. But workers also organized themselves along the lines of ethnicity to secure work. In 1938, 1,000 Chinese workers at the Tanjong Pagar Labour Company staged a lightning strike, after which the TPLC agreed to a further increase in wages. During this lightning strike, Indian workers took the place of the Chinese strikers and so port work was not interrupted. ${ }^{62}$ After the strike, the TPLC workers planned to form a union that would be confined to Chinese workers and exclude any Indian workers employed at the TPLC. ${ }^{63}$ The goal of the Chinese workers was to better protect themselves against workers of different ethnicities who might not hesitate to take their work. In August 1939, after a dispute with workers over pay, the TPLC agreed to allocate night work to Chinese workers first before Indian workers and only hire Indian workers if the number of Chinese workers was insufficient. ${ }^{64}$ Both cases demonstrate that workers organized effectively as blocs and prioritized securing their own access to work in a system of employment that stimulated competition between Indian and Chinese workers.

After World War II, in response to high costs of living and limited rice rations, workers frequently struck work throughout 1945 and 1946. But solidarity was rare. One of the few instances of solidarity occurred in October 1946 when the GLU and SHLU organized a massive strike at the SHB: 10,000 workers stopped work after the SHB refused their demands of doubled wages and larger portions of rice at meals. The SHB could not turn to an alternative source of labor supply and the strike continued for 20 days until the SHB agreed to increase wages by $15 \%$. Security service officials lamented that the GLU had 'quickly showed that its control over the workers was complete.' ${ }^{65}$ But the GLU and SHLU had limited influence among all the workers because of the ethnic divisions of labor. In July 1946, the GLU called for a strike among port workers twice before 8,000 workers walked out on a partial strike, during which all Indian workers went on strike, while $35 \%$ of Chinese workers continued to work. ${ }^{66}$

61 "S.H.B. labour trouble settled," Morning Tribune (22 Sep. 1938): http://eresources.nlb.gov.sg/newspapers/Digitised/Article/morningtribune19380922-1.2.19 [Accessed: 14 Sep. 2020]. 62 "S.H.B. workers to form trade union," Morning Tribune (27 Feb. 1939): http://eresources.nlb.gov.sg/newspapers/Digitised/Article/morningtribune19390227-1.2.46 [Accessed: 14 Sep. 2020]. 63 "Monthly review of Chinese Affairs," August 1939, TNA/CO 273/654/13; "Labour differences settled," Straits Times (25 Aug. 1939): http://eresources.nlb.gov.sg/newspapers/Digitised/Article/straitstimes19390825-1.2.81 [Accessed: 14 Sep. 2020].

65 "Malayan security service political intelligence journal No. 14," 15 Nov. 1946, TNA/FCO 141/15954.

66 " 8,000 dockers call strike," Malaya Tribune (25 July 1946):

http://eresources.nlb.gov.sg/newspapers/Digitised/Article/maltribune19460725-1.2.10 [Accessed: 8 Aug. 2020]; "Harbour 


\section{DeCASUalization AND THE Legacies OF LABOR CONTRACTING}

In October 1947, after frequent strikes and labor action, the SHB announced it would end the labor contractor system and shift to direct employment of workers. There were several factors that led to decasualization. Firstly, the SHB was increasingly unhappy with the contractor system because of the contractors' high margins of profit. Meanwhile, labor costs were high while port charges were low. ${ }^{67}$ Secondly, labor unrest in 1946 led to a loss of 252,780 man-days. ${ }^{68}$ Under the employment of contractors, workers protested their low pay and working conditions. For the SHB, the costs of the contractor system now outweighed the benefits. Workers also could not be easily replaced because the routes of immigration from China and India had closed. Thus, the October 1946 strike was particularly impactful because the SHB could not replace the striking workers.

After it decided to decasualize workers, the SHB negotiated with the three unions separately. The unions did not act in unison. By the end of 1947, the SHB had reached agreements with two of the unions, the Ship and Wharf Labour Union and the SHB Employees Union. ${ }^{69}$ But the third union, the Singapore Harbor Labour Union, refused to agree that its members should work for the SHB once the contractor system was abolished and, according to the SHB, tried to impede decasualization. But the SHLU's refusal did not stop decasualization and the SHB ended the contracts with the labor contractors. ${ }^{70}$ In January 1948, the SHLU went on strike, ostensibly to press the SHB to agree to its demands on overtime pay and meals for workers, and claimed that negotiations for decasualization were an entirely separate matter. ${ }^{71}$ The SHB chairman accused the SHLU of vocally supporting decasualization but actually impeding it with this strike. ${ }^{72}$ The SHLU failed to gain support during the strike, partly because other unions did not the strike. Two days later, the strike ended and the SHLU signaled it was open to reaching a settlement. $^{73}$

Board workers back today,” Straits Times (26 July 1946):

http://eresources.nlb.gov.sg/newspapers/Digitised/Article/straitstimes19460726-1.2.32 [Accessed: 8 Aug. 2020].

${ }^{66}$ Wong, "The Singapore Harbour Board," 34; Yeo Piah Woon, "The Singapore Harbour Board, 1946-57" (B.A. thesis, University of Singapore, 1975), 21-23.

${ }^{67}$ Yeo, "The Singapore Harbour Board," 34.

69 "SHB direct labour in February," Straits Times (28 Dec. 1947):

http://eresources.nlb.gov.sg/newspapers/Digitised/Article/straitstimes19471228-1.2.24 [Accessed: 8 Aug. 2020].

${ }^{70}$ Singapore Harbour Board, Report \& Accounts (Singapore: 1948), 11.

71 "SHB men's threat to strike," Malaya Tribune (8 Jan. 1948)

http://eresources.nlb.gov.sg/newspapers/Digitised/Article/maltribune19480108-1.2.21 [Accessed: 8 Aug. 2020].

72 "Dock strike gets underway: 5,000 halt work," Morning Tribune (10 Jan. 1948):

http://eresources.nlb.gov.sg/newspapers/Digitised/Article/morningtribune19480110-1.2.7 [Accessed: 8 Aug. 2020].

${ }^{72}$ Singapore Harbour Board, Report \& Accounts (Singapore: 1948), 11. 
The SHLU may have opposed decasualization because of its reliance on the contract system to build up its funds and because mandores, who found reliable employment with the contractors, were members of the union. ${ }^{74}$ At a meeting with the various unions, Tan Chiu Tin, a chief mandore and member of the SHB Wharf Workers Mutual Aid Association (which had a reputation as dominated by the contractors), claimed that ending the contract system would not benefit the workers and that decasualization would only benefit the SHB because it would be able to divide the unions. ${ }^{75} \mathrm{Si}$ Ah Seng, the head of the Chinese section of the SHLU, opposed the abolition of the contractor system and said the only way out was to repudiate the agreement. Prior to the meeting, Tan offered to Si that the mutual aid association would pay the SHLU \$3,000 in exchange for the SHLU's rejection of the decasualization agreement. ${ }^{76}$ It is not clear if this transaction occurred, but it is clear that the contractors and mandores worked with some unions to attempt to stop decasualization. The SHLU also continued to maintain a relationship with S. L. Perumal, who ran the Indian Labour Company after taking over from B. Govindasamy. For example, Perumal and the SHLU jointly managed an account to fund a Tamil school run by the union. ${ }^{77}$

The continued ethnic division of labor undercut solidarity between unions because workers continued to make demands as ethnic blocs and could now be replaced by different unions, rather than different contractors. For example, on the eve of the Lunar New Year in 1948, the Ship and Wharf Labour Union (whose members used to belong to the Cantonese Labour Syndicate) went on strike for one day after the SHB refused to grant extra pay for working on the Lunar New Year holiday - a holiday benefit that the Cantonese Labour Syndicate used to give to its workers. Around 625 SWLU workers walked out and, in response, the SHB replaced them with members of the SHLU. ${ }^{78}$ A month later, another conflict emerged between the SWLU and the SHLU. Li Cheng, the treasurer of the SWLU, was given the contract of loading scrap iron onto a ship on a piecework basis by the SHB. The SHLU considered this an attempt by the SHB to revive the contract system and intended to call a strike. The strike was averted when laborers warned Li Cheng of the impending labor disruption and he, in turn, reported the possible strike to

\footnotetext{
${ }^{74}$ Yeo, "The Singapore Harbour Board," 37; "MSS Singapore weekly summary no. 8," 21 Feb. 1948, TNA/FCO/ 141/15957; "MSS Singapore weekly summary no. 17," 1 May 1948, TNA/FCO/141/15957; "MSS Singapore weekly summary no. 20," 22 May 1948, TNA/FCO/141/15957.

74 "Singapore Local Intelligence Committee report no. 67," 1-8 March 1948, TNA/FCO/141/15957.

${ }^{76}$ C.M.J. Kirke, "MSS Singapore weekly summary no. 4," 23 Jan. 1948, TNA/FCO/141/15957.

76 "MSS Singapore weekly summary no. 20," 22 May 1948, TNA/FCO/141/15957.

77 “MSS Singapore weekly summary no. 7," 14 Feb. 1948, TNA/FCO/141/15957.
} 
the SHB authorities. On the day of the intended strike, the SHB issued orders that work on the ship in question would be carried out by work gangs drawn in rotation from the SHB pool of labor, thus preventing accusations that work had been allocated by contract. ${ }^{79}$

The most explosive conflict between the unions occurred in April 1948. The SHLU claimed that although the contractor system had ended, the SHB had not met their demands regarding food, housing, and medical facilities. The police had also raided the union premises and arrested some of the union officers. ${ }^{80}$ After a mass meeting attended by about 600 people, consisting mainly of Indian workers, the SHLU called a strike on 17 April. The next day, despite the SHLU's call for a strike, about 1,200 Chinese workers returned to work. ${ }^{81}$ Their return incited violence. There were reports of Indian workers stabbing Chinese mandores and laborers at the laborers' quarters, and a hand grenade was thrown at workers leaving the SHB through a gate near the quarters. ${ }^{82}$ On 19 April, there was $100 \%$ turnout of laborers required by the SHB but on 20 April, there was a complete stoppage of work. Chinese workers cited intimidation and assault by Indian workers as reasons for joining the strike. The SWLU and the SHBEU then asked the SHB authorities to guarantee indemnity to any worker assaulted outside the SHB. If this were granted, those two unions would be prepared to continue work but not on ships near where Indian workers were usually based. ${ }^{83}$ Already prepared to undermine the SHLU, the SWLU and the SHBEU aimed to secure work for Chinese workers in a situation where violence was drawn along ethnic lines.

These divisions between workers remained in place throughout the 1950s and manifested as rivalries between the unions, which the SHB and workers sometimes used to their advantage. In June 1953, A.M. Doraisamy, the secretary of the SHLU, denounced the SHB Employees' Union for failing to make demands to the SHB on a joint basis with other unions. ${ }^{84}$ Some workers who were unhappy with the Employees' Union and the SWLU's lack of progress with securing workers' demands then approached Doraisamy to be allowed to join the SHLU. Doraisamy initially refused, most likely because he had been trying to form a federation between the unions and did not want to stoke tensions

\footnotetext{
78 “MSS Singapore weekly summary no. 11," 13 Mar. 1948, TNA/FCO/141/15957.

79 "Dockers give 24 hour ultimatum to SHB," Malaya Tribune (16 Apr. 1948):

http://eresources.nlb.gov.sg/newspapers/Digitised/Article/maltribune19480416-1.2.36

[Accessed 8 Aug. 2020].

80 "MSS Singapore weekly summary no. 16," 24 Apr. 1948, TNA/FCO/141/15957.

${ }^{81}$ J.C. Barry, "Singapore Central Intelligence Department, monthly crime reports," Apr. 1948, SOAS/WBC/PP MS 31/Box 8/File 36.

82 "MSS Singapore weekly summary no. 16," 24 Apr. 1948, TNA/FCO/141/15957.

83 “weekly summary no. 22," 6-13 June 1953, TNA/FCO/141/15962.
} 
with other unions. But after his conflict with the Employees' Union he changed his mind and started printing leaflets in Chinese to try to attract Chinese workers to join the SHLU. ${ }^{85}$ Meanwhile, the SHB was content to deal with the unions individually and encouraged the so-called 'Chinese' unions (the SHBEU and SWLU) to make their demands to the SHB independently, which the SHB promised would likely be met. ${ }^{86}$ Unions remained divided until they merged with the SHB Staff Association (SHBSA) in 1960. In 1963, after the SHBSA's left-wing leaders were arrested during Operation Coldstore (a government operation to arrest left-wing political figures and activists), the SHBSA was de-registered and subsequently reconstituted as an affiliate of the PAP government-controlled National Trades Union Congress (NTUC) ${ }^{87}$ In 1968, the PAP further reduced the power of labor unions through new industrial relations legislation with the justification of economic survival, which left no room for labor unrest. ${ }^{88}$ The Singapore Port Workers' Union, the successor to the SHBSA, is now a partner to management and regularly stands by management's decisions. ${ }^{89}$

Decasualization ended the labor contractor system but aspects of the contractor system endured. The management of labor by ethnicity shaped how workers organized to make demands and how unions were formed after World War II. The ethnic divisions between workers and unions made joint action by the unions difficult, but it did not prevent the workers from making their demands known. When no alternative sources of labor could be found, strikes by workers in an ethnic bloc were effective, and occasionally all the unions called for strikes, such as in October 1946. This strike compelled the SHB to consider decasualization, and in the 1950s the SHB embarked on welfare measures, such as building more workers' quarters. Although contractors and intermediaries were forces of subordination in the port, there were also opportunities for workers to make demands as ethnic blocs to secure work, and they continued to organize by ethnicity even after the contractor system ended. These actions call for more study of how labor and workers' interests can be conceptualized. For the SHB workers, the end of the contractor

\footnotetext{
84 “Weekly summary no. 29," 11-18 July 1953, TNA/FCO/141/15962.

85 "Weekly summary no. 35," 22-29 Aug. 1953, TNA/FCO/141/15962.

${ }^{86}$ Poh Soo Kai, Tan Kok Fang and Ho Lysa, eds., The 1963 Operation Coldstore in Singapore: Commemorating 50 years (Kuala Lumpur: Strategic Information and Research Development Centre, 2013); Joshua Chia Yeong Jia and Makeswary Periasamy, "Singapore Harbour Board Staff Association," NLB EResources (10 May 2016): https://eresources.nlb.gov.sg/infopedia/articles/SIP_1158_2008-11-30.html [Accessed: 10 Sep. 2019].

${ }^{88}$ Arthur de la Mare, "Annex to despatch on new labour legislation," 18 Oct. 1968, TNA/FCO/24/552.

${ }^{88}$ Peter Turnbull and Victoria Wass, "Defending dock workers - Globalization and labor relations in the world's ports," Industrial Relations: A journal of economy and society 46, 3 (2007), 599. The Singapore Port Workers' Union has pointed to 1972 as a turning point for the union when they began a more cooperative relationship with management. Singapore Port Workers' Union, “Singapore Port Workers' Union (a brief history),” NAS/NA 904.
} 
system did not result in the emergence of a unified working class that thought of workers in universalist terms. Instead, calls for fair pay and improved working conditions were forged within a system characterized by ethnic divisions.

\section{CODA}

Beginning in the 1960s, both the SHB and its successor, the Port of Singapore Authority (PSA), attempted to remove divisions of ethnicity from the workforce. The SHB introduced racially integrated gangs, in which workers of multiple ethnicities worked under a foreman who was of a different ethnicity, and then the PSA trained employees to work as both stevedores and wharf workers, and to operate forklifts and handle containers. ${ }^{90}$ Gangs were eventually abolished in $1985 .{ }^{91}$ But the PSA continued to rely on migrant workers, mainly from Bangladesh, India, Malaysia, Indonesia, and China, to work under the supervision of Singaporean citizens. ${ }^{92}$ Contract workers are not trained as container equipment and machinery specialists. They are mainly responsible for container lashing and driving, and they are not permanently employed.$^{93}$ Now the organization of difference between port workers is premised on citizenship, rather than ethnicity. Migrant workers constitute around one-third of Singapore's workforce, and many of them are employed in the construction and transportation industries, as well as at the container port run by the PSA. Singapore's shift to a knowledge economy with a focus on tertiary sector services is be reserved for citizens and expatriates. Migrants who hold white-collar jobs, often classed as expatriates, have the option of applying for residency, but the path to Singaporean residency is closed to migrant 'guest' workers in construction and shipbuilding industries.

The persistence of ethnic identities within labor struggles in Singapore has been exacerbated by continued reliance on migrant workers whose working and living conditions are strikingly similar to those at the port before decasualization. Since 1968, only a few major labor strikes have occurred in the city. The most recent major strike occurred in 2012 when 171 bus drivers, all of whom were Chinese nationals, went on strike to protest their lower pay compared to their Malaysian counterparts. Chinese

\footnotetext{
${ }^{90}$ Yee Kwye Yoong, "A study of the unattached labourers - both the currently employed and the retired - who are residing in the Singapore Harbour Board "bachelor" quarters" (B.A. thesis, University of Malaya, 1961), 22; Curless, "Triumph of the State," 1121; "Comments on report of the Tripartite Technical Meeting on dock labour, Rotterdam, $14^{\text {th }}$ to $25^{\text {th }}$ April 1969," 4 Aug. 1970, NAS/Ministry of Labour/1117/ML/ILO/TT/5.

90 Turnbull and Wass, "Defending dock workers," 600.

92 David Chin Soon Siong, interview by Patricia Lee, 18 Oct. 2007, accession number 003225, reel 5, NASOHC.

92 Turnbull and Wass, "Defending dock workers," 600.
} 
nationals were employed on two-year contracts and housed in dormitories with 10 to 12 workers to a room, whereas Malaysian nationals were permanently employed and not provided housing because they were expected to commute between Singapore and Malaysia every day. The Singaporean government declared the strike illegal and imprisoned five strikers, while another 29 drivers were repatriated to China after their work permits were revoked. ${ }^{94}$ Singaporeans' frustration with the strike turned into calls for the Chinese workers to 'go back to [their] own country.' 95 These differentiated contracts and living conditions are reminiscent of the conflicts at the harbor between directly-employed and casual workers that often became ethnicized, and the deportation of migrant workers is a tactic that colonial officials often used after a strike or a protest.

Migrant workers in Singapore received renewed global attention in 2020 during the covid-19 pandemic. An outbreak emerged in migrant workers' dormitories where social distancing was not possible because of cramped conditions in shared bedrooms, bathrooms, and common areas. At the beginning of May 2020, Singapore recorded over 25,000 cases of covid-19, of whom the majority were migrant workers. ${ }^{96}$ Features of the contractor system established in the nineteenth century are startlingly apparent today: crowded dormitories, migrants largely from South Asia and China, and recruiting agents who charge fees that often lead to debt. Tanjong Pagar housed migrant workers again, but this time workers lived on floating accommodations at the port. ${ }^{97}$ From the view of the harbor, amidst the cranes and containers, post-colonial Singapore and the flows of migrant labor do not look so different.

\footnotetext{
${ }^{93}$ Cheryl Sim, "SMRT bus drivers' strike," NLB EResources (15 Mar. 2015): https://eresources.nlb.gov.sg/infopedia/articles/SIP_2015-03-11_162308.html [Accessed: 24 May 2021]; “Singapore jails bus drivers for inciting strikes," BBC (25 Feb. 2013): https://www.bbc.com/news/world-asia-21571053 [Accessed: 24 May $2021]$.

${ }^{94}$ Haroon Siddique, "Singapore's first strike in 25 years shines spotlight on racial tensions," The Guardian (28 Nov. 2012): https://www.theguardian.com/world/2012/nov/28/chinese-bus-drivers-strike-singapore [Accessed: 24 May 2021].

95 Jessie Yeung and Isaac Yee, “Tens of thousands of Singapore's migrant workers are infected," CNN (14 May 2020): https://www.cnn.com/2020/05/14/asia/singapore-migrant-worker-coronavirus-intl-hnk/index.html [Accessed: 14 Sep. 2020].

${ }^{96}$ Lim Min Zhang, "Coronavirus: 2 floating accommodation at Tanjong Pagar Terminal to house foreign workers," Straits Times (12 Apr. 2020): https://www.straitstimes.com/singapore/coronavirus-2-floating-accommodation-at-tanjong-pagarterminal-to-house-foreign-workers [Accessed: 14 Sep. 2020].
} 